\title{
岡崎文彬
}

\section{Jean-Jacques Rousseau et Ermenonville}

par Ayaakira OKAZAKI

\section{1. ルソーにおける自然主莪と庭園観}

1778年 5 月20日、ジラルダン侻の好意でエルムノンヴ

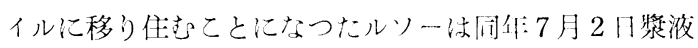
性卒中のためそこで急逝した。

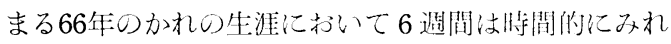
ば一格にすぎないが自然主䉝に销したかれにとつて、ま た四面楚歌の晩年のかれにとつて、エルムノンヴィルに おける日暮は深い㦘いであつたにちがいない。

18世紀をきつてのフランスの大思想家であるルソーに ついてはあまりにも多くの研究がなきれているが、ここ にはかれの自然主義に襄打ちされた庭園観をさぐつてみ たい。

生後10日で母在亡くした不運はともかく、10才にして 父の出奔化あいわずか13才で従弟奉公に出されたジャ ン・ジャックの幼少年時代はなんといつても不幸だつ た。それを後のかれの生活、思想との関連において磪み るとともむろん大切である。たと充ばかれはジュネーヴ 郊外のボセ一の牧師ランベルシエに、同年の従兄鹈とと もにあずけられたが、そとでの川闧生活が自然への関心 を呼び起したととが十分に推定される。ただ罣作につい てみるが可故国ジュネーヴにおけるかれ、い、いわれ われの考察の対象とはなりがたい。

1726年に始まるか机の版浪生活、その闃に知りあつた ヴアラン夫人との共阔生活注かれが不朾の薯「告白」で 述懐していると扔り、生海在通じての、かれの最も幸福 な時期であつたにちがいない。

自己教育のこの期閂に作つた「ヴアラン男爵夫人の果 樹園」(Le Verger de Madame la Baronne de Warens) 注かれのヴアラン夫人に対する讃歌であるが、アカデメ イアの幻想に満ちているし、シャルメットでの生活の幸 福を歌いあげたものに外ならない。

ルソーにおいては自然はつ权にかれの内面の投影であ ろうが、かれの母なる自然への憧憬の奥にヴアラン夫人 の面影が宿つていなかつたとはいい切れない。

と注い光、自然詩人としてのルソーを伺う上㵊も重 要な著作は1761年に出版された「新エロイーズ」(Julie ou La Nouvelle Héloise) と、死の直前 (1777 78) に書

京都大学農学部造園学研究室
きあげられた「孤独な散歩者の装想」(Les Rêveries du Promeneur Solitaire) である。

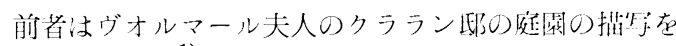

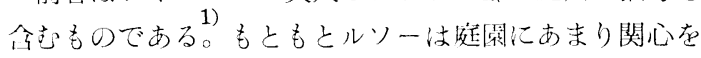
もたなかつたといらが、それ泣当将のフランスの庭圊が 空前の人工式のあらわなもものだつたからである。それら のうちではソーの庭園が気に人つていたというが、ソー に㳊部分的に自然風なとり投いがあつたからではなかる

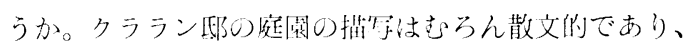
そこから当時の庭嗍の资在铰密に描き出すことはできな いにしても、か扎注自然風な庭園のあり方濽詞を惜し んではいないのである。

「孤独な散少者の夢想」に注往年の激情と諦観とが交 錯しているか、自然についてとくにふれているのは「第 2 の散歩」と「第 5 の散歩」とである。わけても「第 5 の散步」にはか的が生涯のうち最もすばらしいと感じた ビエー又湖の真中にあるサン・ピエール島が描军されて いる。モテイ土在石で迫われたルソー牥てこても2か 月以上㴋在することを許してもらえなつたが、島のただ 一棟の家法、かれにとつて注正しく别天地であつたとつ ぎのように述懐している。

「周困が半里しかないての小島の家は住:こここちがよ く、便利にできていて收税官が家族と骕人をつれて住ま つていた。そこに法家小展や養魚池があつたが、その 大地や眺望は変化にとんでいる。冒、ぶどう栭、森、果 樹園、牧草地があり、水讱に䧔影をつくる木立におおわ れているが、そこ在灌木が緣どつている。なお島には二 列に樹木の植わつた高台がつづき、その中ほどには美し い園亭がつられていて、ぶどうの収俨期の日曜日には 近くの湖畔の人赫がてこに集つてきて踊つたりする。」 風景式庭園はハルバウムには上机ば
(1) 自然式
(2) 前期浪漫感賃式
(3) 古典式
(4) 浪漫式

の順で発達したが、ルソーが興味をもつたと思われるの 注前期浪漫感傷式のものとい充ようか。もつともそれは かれがエルムノンヴイルに満足していたととと関連して 推定されるだけで、風景式庭園の後期のものを知らずに 
逝つたかれであり、また庭園の専門家でないかれが見聞 した風景式庭園はでく限られていたにちがいない。しか しそれらはかつての整形式庭園とは対蹨的であり、比べ ものにならないほど自然の要素を尊重しているという意 味で、すべての風景式庭園はか机にとつて歓迎さるべき ものであつたろう。

\section{2. ルネ・ジラルダン侯とェルムハンヴイル}

マルタン・デカ

ン゙はジラルダン

侯についての詳綀

な書を著わしてい

るが、䢃頭ジラル

ダンのととを偉大

な領主であり、不

思議な芸術愛濩者

であり、田園美に

異常な愛着をもつ

芸術家でもあると

評している。

ルネ・ジルダ

ンは1735年にパリ

で生まれ、1808年

にヴェルヌイエで

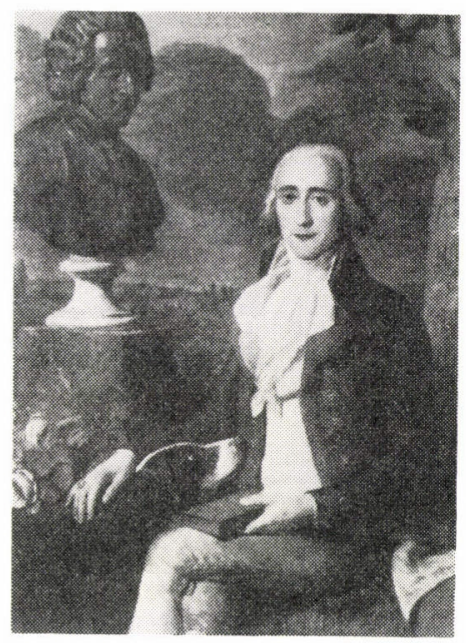

四1 ルネ・ジラルダン侯

(グルーズ画)

死んだ。エルムノンヴイルからは離れているが、死の床

でかれの脳弿に去来したものは哲学堂とルソーの墓場の

あるエルムノンヴイルの期宅ではなかつたらうか。

かれの容姿は端正で貴族的であり、当時流行のヴエル

テル風の服装をしていたととがグルーズの描いた肖像画

(図1）功わかる。

ジラルダン家はもともとイタリア系の家でゲラルデイ

ニ (Gherardini) がフランス式のジラルダン (Girardin)

そ変わつたものであり、血からいつても矦が芸術愛好家 であり、後世にいう前期ロマン感傷派の情熱家であつた ととがよく理解される。

もつとも多くの当時の名門と同じくルネ・シラルダン も初めは陸軍に入り、ポーランド王、ロレーヌ公スタ二 スラス・レチンスキーの宮廷付武官となり、大公が亡く なるまで忠実に仕えたといわれる。1761年りユネヴイル でブリジット・ベルトロー・ドウ・ベイ锺と結婚したか れは男児 4 人、女児 2 人に恵まれたが、1765年に生まれ た長子スタニスラスは後年「回想録」のなかで父のこと や、エルムノンヴィルの所領についての記載を行なつて いる。

前述したように大公の死んだ1766年以降1776年まで10 年がかりで、かれは自分の所領となつたエルムノンヴイ ルに自然式庭園を構築したのである。

余談だが、われわれはことに後年のピュックラーがシ
ラルダンとよく似通つた道を歩んだことを思い出すので ある。

エルムノンヴイルの館についてはことには多くふれな い。それはわれわれの目標が庭園にわかれているためだ けでなく、半ぱ中世に、半ば17世紀に追加されたこの館 は建築的にとりたてていうほどのものではないからであ る。もつとも㞔の時代にも補修はされているが、アレク サンドル・ドウ・ラボルドのいうとおり、「エルムノン ヴイル城を改良するととはできても、その位置をよくす るととはできなかつた」のである。

さて庭園であるが、ここは候によつて新しく構築され たといつてもよい。そして侯がてれをつくるにあたつて ルソーの「新エロイーズ」に描かれた理念がとり入れら れたことが注目に值するのである。

ジラルダン侯の子息の教育はルソーが1762年に著わし た「エミール」に基づいて行なわれたといわれるか、方 ふさがりの老年のルツー夫妻をエルムノンヴィルに招い てここに住まわせた一事からしてもジラルダン侯がどの ようにルソーに傾倒していたかがわかるであろう。もつ ともジラル文侯がルソーにはじめてあつたのは1776年 のととであり、それも面白いととに、2人をとりもつた のは文学でも哲学でもなく音楽であつたが、ジラルダン 侯がそれ以前からルソーの著書を通じてかれに深い尊敬 の念を抱いていたととは明らかである。

ルソーがエルムノンヴイルで急逝するやジラルダン侯 は悲僅のうちにもすかさず彫刻家のウードンに依頼して ルソーのデス・マスクを作らせているが、庭園の上で注 目すべきは深夜棺を「ポプラの小島」に移しているとと である。

以後ポプラの小島は風景式庭園の重要な局部となり、 同様の島はルソー島と呼ばれるととになつた。たと光ば ヴエアリッッの庭園にはエルムノンヴィルと見まごう小 島が設けられている。

さてジラルダン矦がエルムノンヴイルの領地に展開し た楽園は大きく二つの部分に分かれる。

その一つは感傷的ならびに冥想的な風景式庭園 ( Le jardin paysager, sentimental et philosophique) であり 他は田園牧歌的な桃源境 (L'Arcadie géorgique et bucolique) である。大まかにい光ば池の周辺の比較的細かい 手法の平坦部が前者であり、西部の森林に接した小高い 部分が後者というととができよう。

ジラルダン矦がてれを築造するに先立つてしばしば外 国旅行をしていたとと、そしてとくにイギリスに路いた ことが風景式庭園をつくる上に大きな影響を及ぼしてい ることは否めないと思う。たとえばウイリアム・ケント がノーフオークの伯爵領につくつたホルカムの居城の庭 園、ミロード・コバムの風景式庭園、ならびに詩人ウィ 
リアム・シエーンストンの庭園内の洞兾、廃墟、瀑、オ ベリスク、岩山といつたもののイメージが後年エルムノ ンヴイルの作庭に実現されていると考えるととができる のである。

「自然が提供するものを受けいれ、自然の拒否するも のは保続しないととを知り、それが容易で簡単なものを 実行に移すべきである」というのが、ジラルダンの造庭 に対する信条であつたようである6)。

かれの庭園観と外国旅行がエルムノンヴイルを風景式 庭園につくり上げる根本的な動機となつたが、その計画 が本格的なものにかたまるまでにはモレルの設計、ユベ ール・ロベールのデツサンが参考とされただけでなく、 旅行中すでに何枚かのマスター・プランがかれ自身によ つて描かれている。たとえば園内のアルカディーについ てはエシオードとテオクリツトの詩、ヴイルジールの「 田園と牧歌」(Les Géorgiques et les Bucoliques) からジ エームズ・トムリンの「四季」(Saisons)、かれの友人で あつたゲスナーの「田園詩」(Idylle) にいたるまで、そ こに描写されたアルカデイーが檢討されたにちがいな い。またペトラルカの「田園詩、1360年頃」、セルバン テスの「ガラテア人」(La Galatée、1584)、サナツアロ の「アルカデイー、1480」、フイリツプ・シドニーとマ リー・ドウ・パンブロークの「アルカディー、1590」、 ヴエガの「アルカディー、1603」、フォントネルの「牧 歌の本質論」 (Le Discours sur la Nature de l'Eglogue、1688）、とくに1709年に発表されたアレクサレダー ・ポープの「田園風景」とベルニの「フランスの田園、 1763」がかれの胸にまざまざと浮かび上がつていたにち がいない。かれが当代きつての文学通であつたととから もとれは容易に想像されるところである。

ジラルダン矦がエルムノンヴイルの庭園の一部をアル カデイーとしたのはとの庭園に桃源境を再現するためで あつた。18世紀になつて自然が「再生された」ととは事 実であるが、それは華やいだ美しい社交場を提供するた めではなく、哲学的、人道的なイデーの化身としてのも のであつた。そしてジラルダンのアルカデイーはまさし くそうしたものを具現したといえる。

アルカディーの部分に対し、平坦な風景式庭園の部分 は冥想の園といえる。この部分の築造にあたつてはジヤ ン・ジヤツク・ルソーの数多の著述がジラルダンの胸中 に一杯にひろがつていたであろうが、わけても1761年の 新エロイーズは繰り返し読みかえされたにちがいない。

\section{3. エルムノンヴイルとルソー}

すでに述べたとおりルソーはわずか 6 週間しかエルム ノンヴイルに滞在しなかつた。しかもととへ移つた1778 年 5 月20日までての館を知らなかつたのである。それに
もかかわらず かれと前期口 マン感傷派の 庭園の代表で あるエルム， ヴィルとの関 係の深いのは かれがことに おいて安住の 憩をみたか らであり、ま たかれの霊が ここに永眠し ているからで ある。

42日間,ル ソーはジラル ダン侯とは同

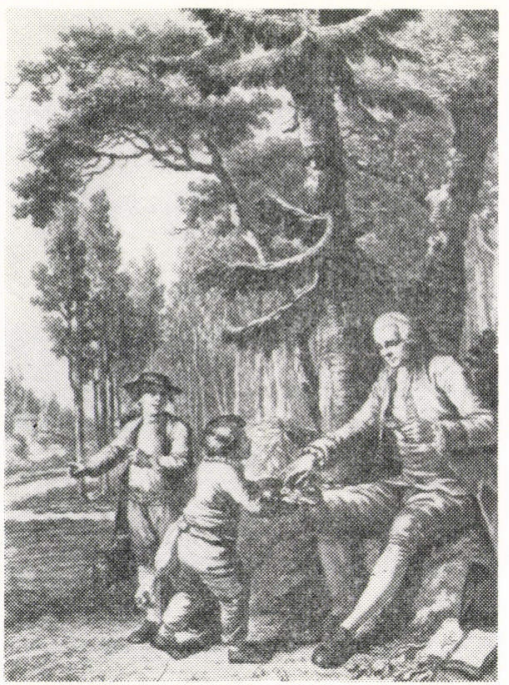

図2エルムノンヴィルでジラルダン矦 の子供らと遊ぶルソー（ル・ミー ルの画)

じ屋敷の別棟にいたのであり、集と日常生活をともにし たわけではない。むしろことで冥想し、天然の草花と親 しみ、湖上を静が漕ぎ回るのがルソーの日課であつた らしい。新エローズに描かれた「千羽の小鳥」を思いな がら繁みにされ遊ぶ小鳥に款物を与え、また湖上の魚に パン局を投げ与えることを欠かしたてとのないかれであ つた。なおその他の動物にもルソーがどのように深い関 心をもつたかはジルダン父子の伝記やベルノーの「エ ルムノンヴイルの旅」その他の記録について認められ る。しかしかれはここに棲息する動物以外のものを飼育 しようと考えたととはなかつた。また当時流行の外来の 植物をとこにもち込みたいとも思わなかつた。けだし自 然人であるルソーとしては当然のことであろう7)。ただ しその滞在中ルソーはジラルダン侯の子供らと遊び、エ ミールの論を地で行くほどかれらに深い愛情を示したこ とがジラダン夫妻の伝記に残つている。（図 2)

「孤独な散歩者の夢想」の著者は上述の二つのパルク の部分だけでは満足しなかつたようであり、庭園をとり まく森林と付近の風景がルンーには大きな鬿力であつた らしい。かれはここにいるあいだ常に朝早くから公園と その周辺を歩いたが、夕方には散歩をしなかつたとい

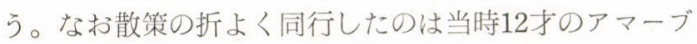
ルであつたらしい。

シャーリとエルムノンヴイルのデセールの管理者とな つたルイ・ジレのいうとおり、ルソーのとこでの6週間の 滞在はかれの著作とは直接なんの関係もない。この間に 1 行の原稿をも認めていないからである。にもかかわら ずここでの生活はかれれとつては文字どおり㮩いであり またかれの夢想が実現した場でもある。かれがェルム， 
[RMENONYII!

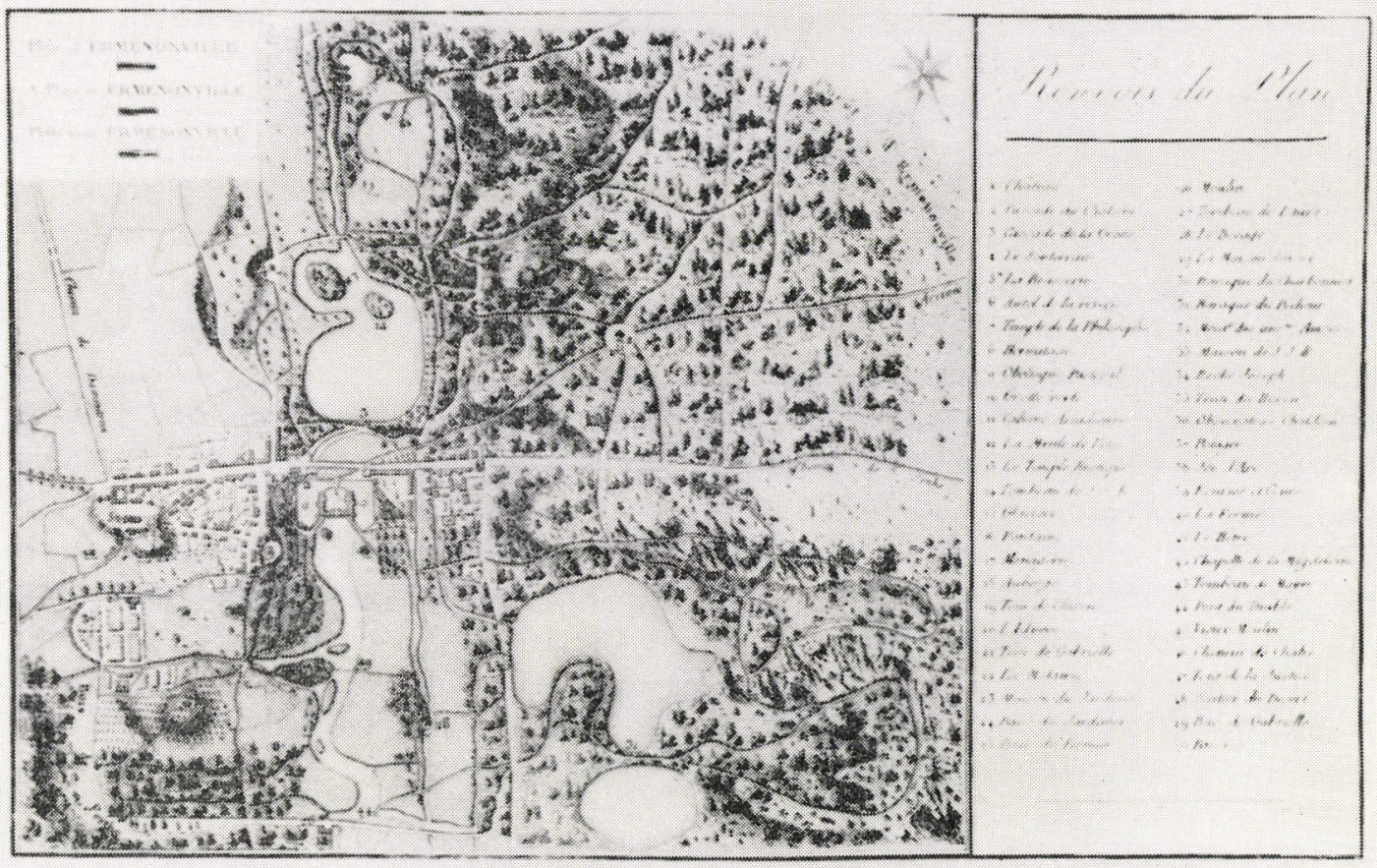

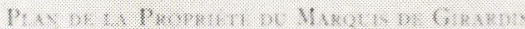

図 3 平 面 図（ラボルドによる）

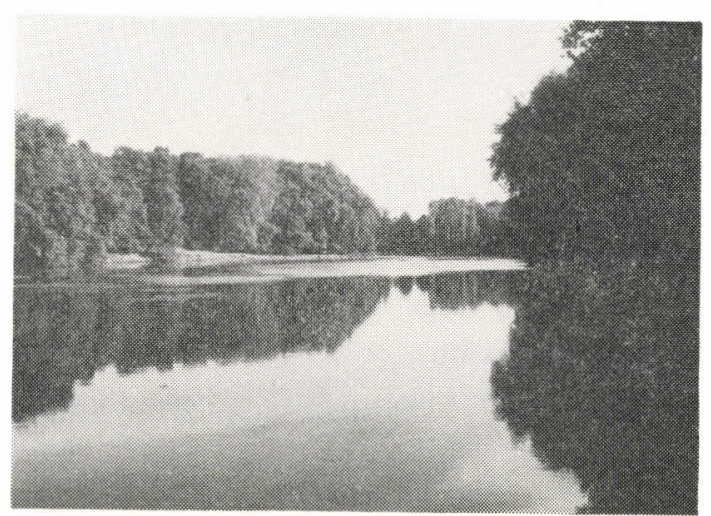

図 4 中央の池（筆者、1963）
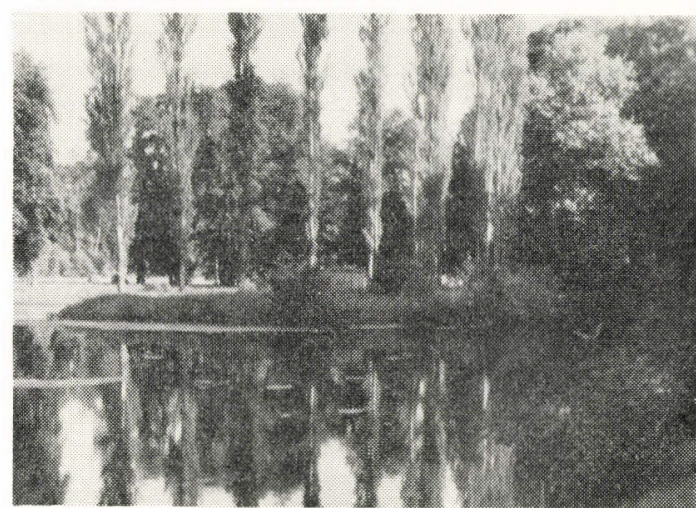

図 6 ルソー島（筹者、1963）

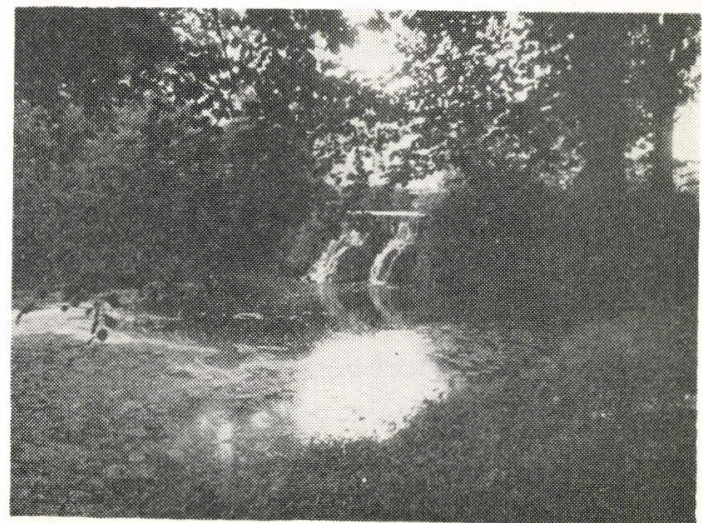

図 5 カスカード（筆者、1963）

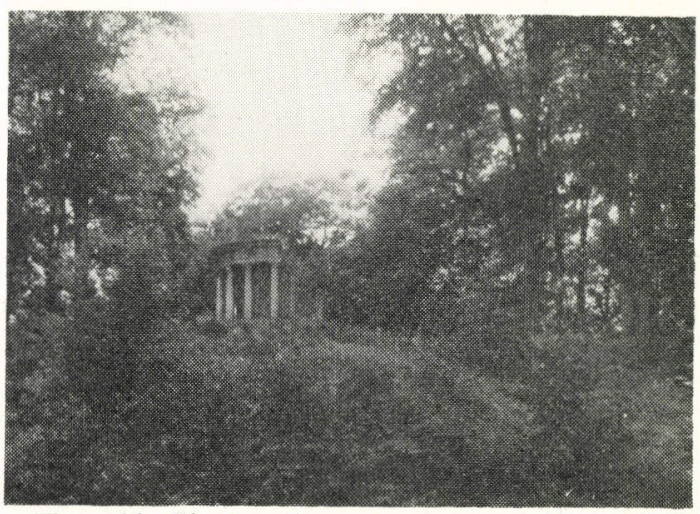

図7 哲 学 堂（筆者、1963） 
ンヴイルに着く数週間前に恋めた散歩者の装想を。

ジャン・ジャツクとともにエルムノンヴイルに移つた 妻のテレーズ・ルヴアスールは誰の記事についてみても 良妻賢母ではなかつたらしい。かれが生まれた子をつぎ つぎと養育院に送つたのもやむを得ない仕儀だつたのか も知れない。

ルソーがエルムノンヴィルに移つてから数日後ヴオル テールが逝去している。84才の高秢のヴオルテールの死 がルソーにそれほどショツクを与えたとも思えないが、 約1か月のうちに18世紀の雨巨頭が消えさつたのである。 ただルソーがエルムノンヴイルで静かに息をひきとつた のに対し、ヴオルテールは死の床で、なおかれの最後の 悲劇「イレーヌ」が上演され、それが拍手喝朵を受ける 光景を思い浮かべていたちがいがあるだけである。

\section{4. エルムノンヴイルの現況と存在の意義}

ルソーの死後、ジラルダン展はそのパルクをルソーの 好みに応じて手入れを続けていつた。ルソーは庭国の整 借について何の意見も出したわけではないが、かれの考 えはとくに新エロイーズを通じてジラルダン侁にはよく 理解されていたのである。

エルムノンヴイルは風景式庭園であるから、ジラルダ ンの時代からみるとかなり変容している。1938年にトウ ーリング・クラブの手に移つてから、いち抽う整備され はしたが、今次大戦以降管理に乃全をはかつてきたとは 思われない。

全景はラボルドの平面図（闵３）のとおりであるが、 西方の林相などはかなり変化したと思われる節がある。 平面図の上半分の東部、池（図4）を中心として風景式 庭路の主要部が展開して抽り、館とはモー一ーサンリス を絬ぶ国道30号線によつて境されているが、これも現状 のとおりである。また日本庭国滰を思わせるような、 自然なカスカード（図 5 ）、ルソ一島（図6）、数々の

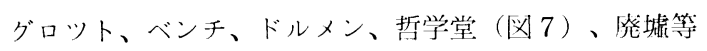
はいずれも健在であるが、それらのあるものはやや位置 をかえるか、それ自体の位置か変化しないまでも周辽の 樹木、地被植物の消長によつて構築当時とは簙なつた様 相を示しているであろうことはたやすく想像される。た だしラボルドの平面网を現状と比べて最も注意しなけれ ばならないことは、上記のボイントとなるものが全園に わたつていまも散在している事史である。後のデッサウ 近くのヴエアリツツの庭園と间様、エルムノンヴイルも 散策回遊して初めて、その風景式庭圆の其価が理解され るのである。すなわち中心的な視帒を固定していないの が著しい特色である。わが国の江時代の回遊式庭園に も認められるように面積が大きくなれば一視点からの特 別の效果を狙うより回遊による観賞を目標において庭圆
が設計されやすくなるのは当然かも知れない。大面䅡の 庭圆でも、たとえば、フランス式庭園を初めヴィテルボ のランテ荘やフラスカデイの多くのヴイラの庭園のよう に観賞の焦点や舳を特定の垈または線に固定しているも のも少なくないのである。それは整形式園に対して風景 式庭園のもつ一般的䝨问といえるかも知れないが、風景 式庭園のなかにあつてエルムノンヴィルがヴエアリツツ などとともに主振されなりればならない柋は、視点が分 散しながらも、それが刎揚の少ない連続体とはなつてい ないことである。たとえばレブトンの「レツド・ブック

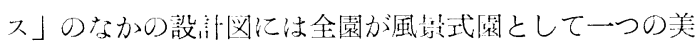
しい連続体在莨成しているものが多いが、そうしたアク セントのない連続性法エルムノンヴイルにはみられな い。その他技师はまるで異なるが、エルムノンヴイル やヴエアリツツなどが他の型の風沾式庭園よりもわが国

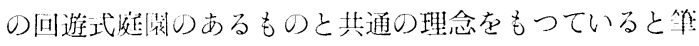
者が主概したいのはそのためである。またそれが㓩期口

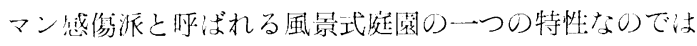
なからうか。

プティ・トリアノン、ランブィ工、パルク・モンソー に注風景式庭園の実態また海名残りが歴然であり、そい

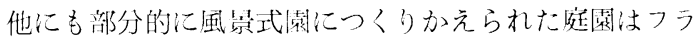
ンスにもいくつか残つているが、ルソーのイデーが端的 にそこに生かされたエルムノンヴイルの庭鬪は㓦期口マ ン感傷派の代表作としてフランスといわず、ひろくヨー

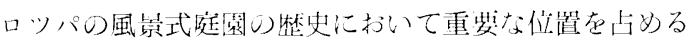
ものである。

$$
\text { 参莎 文献 }
$$

1) Rousseau, J. J. : Julie ou La Nouvelle Héloise.

Lettre $x$, pp. 370

Paris, Garnier Frères, Libraire-Éditeurs 1873

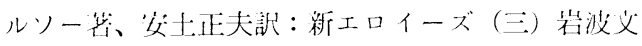
这i 1961

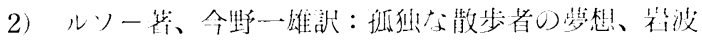
文脑 1965

3) Hallbaum, F. : Der Landschaftsgarten S. 55ff. 1927

4) Martin-Decaen, A. : Le Marquis René de Girardin. 1912

5) Ganay, Ernst de. : Les Jardins de France p. 206 1949

6) Touring-Club de France : Ermenonville 1962 ( ? )

7) Gromort, G. : L'Art des Jardins II p. 93, 1934 
（図板参照）見様に上れば「色」とも読める文字であ る。余があえて「色」を主張する理由洨、この字の出る すぐ前に

「岸より水そこへたていれ又水そこより岸へたてあく るとこなりの石はおほきにいかめしくつつかまほしけれ とも人のちからかなふましき林れは国色の石のかと思 あひたらんを光らひあつりて大なる资代立なすへきな り」

とあり、それに統けて

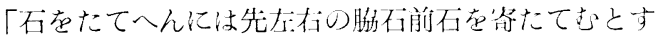
るに思あひ奴へき石のかと有を立をきて奥石をは其石の 口にしたかひてたつる也」

とあつて、石組の技法について形状から色彩に及んで 述べている筒所である。ここでは「沬」などという抽象 的な菜の入る余裕もないほど央地に即した文章だから である。
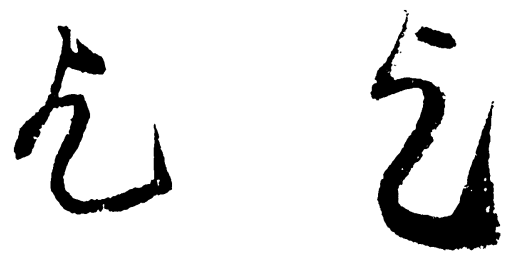

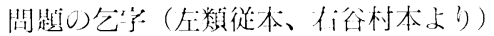

\section{5. むすび}

以上余法「こ法ん」流「公はれ」に非ずして「小半」 なり、又「公」は「色」なりの説を提唱して大方の䍀賢 の御批判右期得するのである。

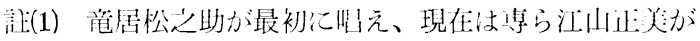

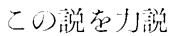

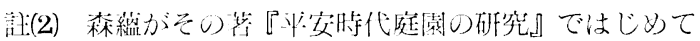
唱光、その後月村㴊もその著『作庭記』でこの説 に间調している。

\section{Résumé}

The word 'Kohan' is mentioned in the "Sakuteiki" five times. Hitherto, on its meaming, two different interpretations are put, namely-'Goban' (A checkerboard), and 'kowan'--that means 'request'. But I found that they are both mistaken and that formerly it meant 'a quarter'. This is the very word, if applied to the referred passages. In the next place, according to my study of the block letters and the contents of the sentences, I found that 'koi '( 2 ) was the misreading of Chinee letter 'iro'. (任)

considérer comme le meilleur jardin paysager de l'époque préromant:que en France.

Le Parc d'Ermenonville a été créé par le marquis René de Girardin d'après les idées de Jean--Jacques Rousseau qui était un admirateur passionné de la nature et qui vécut en ce lieu les six dernières semaines de sa vie. Etant le seul jardin où les idées de la Nouvelle Héloïse ont été ralisées, le nom d'Ermenonville est inséparablement lié à celui de Jean Jacques Rousseau. compte de l'aspect d'un jardin paysager au Petit Trianon, au Parc Monceau et dans quelques autres jardins. Mais c'est le Parc d'Ermenonville qu'il faut

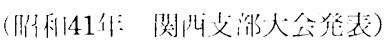

(41. 11. 20 受付) 